\title{
Komunikasi Visual Iklan Cetak Rokok di Indonesia Kurun Waktu 1950 -2000
}

\author{
Oleh: Rama Kertamukti ${ }^{1}$
}

\begin{abstract}
Visual Communication activities in 1950-2000 actual cigarette Advertisement in packaging his message began to flourish in the late 90s with the beginning of the modern trends with ad visualization further highlight the ability to package the message in a way that "new", the Advertisement contains a more interesting originality out of the path message vulgarly without the superior power of creativity is only repeating the old ways of communicating visually compared with 50s. Advertising is a message that offers products intended to the public through a media and advertising is the biggest benefit of bringing the message to be conveyed by the producer to the general public. Sometimes Visual Communication submitted by the Advertisement in the plot that makes the society to behave in a consumptive. Advertising is the tip of the spear, in this case is one of the important parts in the process of achieving success of a program to disseminate, in other words visual communication plays in achieving the goals producer or the sender's main message.
\end{abstract}

Keywords: Visual Communications, Print Ads, Cigarette Advertising in $1950-2010$

\section{Pendahuluan}

Reklame, advertentie atau yang sekarang lebih dikenal dengan iklan, mempunyai sejarah yang panjang. The word of mouth atau pesan berantai menjadi awal dunia beriklan tetapi komunikasi verbal ini mempunyai coverage yang sangat sempit. Iklan mulai dikenal pada jaman Yunani Kuno, utamanya digunakan untuk menyiarkan budak-budak yang lari dari majikannya, atau memberitahu akan dilangsungkannya pertandingan gladiator dengan bahasa tulis. Bentuk yang digunakan adalah dengan menyebarkan surat edaran (brosur). Namun lambat-laun sejalan dengan perkembangan teknologi informasi dengan ditemukannya mesin cetak

1 Dosen Advertising Akindo Yogyakarta 
tahun 1457 oleh Gutenberg perkembangan iklan maju pesat ditopang berbagai suratkabar mingguan yang bermunculan, walaupun penggunaan metode ini pun, tentu saja masih sangat sederhana (Kasali, 1993 : 3). Diawali dengan Revolusi Industri yang pecah di Inggris, kemajuan teknologi memproduksi iklan baru dimulai, bersamaan dengan meluasnya penjualan buku-buku baru, dan surat kabar. Iklan-iklan komersil muncul berupa produk buku maupun obat-obatan.

Sejak awal dikenalnya, iklan telah mempunyai kaitan yang kompleks dengan berbagai perkembangan di bidang-bidang lain. Utamanya, antara bidang-bidang industri dan komunikasi, atau antara perdagangan dan informasi. Hal ini perlu diketahui, untuk memahami perubahanperubahan tujuan, pengelolaan dan metode periklanan pada masingmasing zamannya, merupakan refleksi pada jamannya. Contoh paling baik tentang perubahan dan perkembangan metode periklanan dimulai saat terjadinya revolusi industri di Inggris, yang segera membawa perubahan di bidang komunikasi. Munculnya produk-produk manufaktur berskala-besar, telah menjadikan periklanan suatu kebutuhan mutlak bagi perkembangan ekonomi Inggris saat itu. Setelah Revolusi Industri, Inggris banyak memuat halaman-halaman surat kabarnya dengan iklan untuk memvisualkan produk yang bisa dibeli masyarakat. Surat kabar- surat kabar yang paling menonjol di antaranya adalah The Times dan News of the World. Perkembangan kedua surat kabar ini tentu saja didorong pula oleh kemajuan teknologi percetakan saat itu. Sedangkan dunia iklan di Indonesia juga bergerak menyesuaikan teknologi komunikasi yang berkembang. Di Perpusnas, terbukti bahwa lebih dari 100 tahun yang lalu Indonesia mengenal periklanan. Adanya Suratkabar Tjahaya Sijang (di Manado 1869), yang memuat halaman khusus berjudul "Pemberitahoewan" untuk memuat iklan. Perkembangan yang sangat menarik untuk dicermati adalah penggunaan iklan cetak sebagai media visual untuk beriklan, penggunaan alat yang cetak yang sederhana ini dapat dengan cepat digunakan sebagai media menjual bagi pengusaha di Indonesia, ide kreasi visual dimunculkan untuk menciptakan persepsi sesuai keadaan masyarakat saat itu. Iklan cetak sendiri adalah suatu pesan visual di media cetak yang statis dan mengutamakan pesan-pesan visual. Media ini terdiri dari lembaran dengan sejumlah kata, gambar atau foto, tata warna dan halaman putih. Sungguh menarik mencermati perkembangan sajian komunikasi visual iklan rokok di Indonesia, karena kita ketahui jelas bahwa produk rokok di Indonesia mempunyai peradaban yang sangat lama perkembangannya di Indonesia 
sebagai produk yang dijual di masyarakat dari sebagai bahan obat, gaya hidup, dan sumber penyebab penyakit terbesar di Indonesia. Bagaimana penciptaan visual iklan rokok di Indonesia ketika memulai bisnis masifnya di Indonesia hingga pengaturan berbentuk Peraturan untuk mengatur visual iklan produk rokok yang dibuat. Penggalian ide kreatif visual komunikasi produk rokok sangat menarik untuk dicermati, penghadangan visualisasinya oleh Peraturan yang dibuat oleh Pemerintah dan asosiasi biro Iklan (PPPI) tidak membuat ide komunikasi visualnya miskin pesan untuk berkomunikasi dengan konsumennya.

Dengan latar belakang demikian, maka akan timbul pertanyaan : Bagaimanakah perkembangan Komunikasi Visual iklan cetak Produk Rokok di Indonesia dalam periode awal rokok di Indonesia bermunculan sebagai produk masifhingga sekarang dilihat dari unsur - unsur komunikasi visual yang pembentuknya: tipografi (headline, subhead, body text), warna, gambar, layout ( simetris, asimetris ), bahkan pendekatan semiotikanya (Margolin, 1989).

\section{Dasar Penulisan}

Tulisan ini bertujuan untuk mengetahui proses perkembangan Komunikasi Visual Iklan Cetak produk rokok di Indonesia dilihat secara unsur pembentuk komunikasi visual itu sendiri dan pendekatan semiotika yang dihadirkan dalam visualnya.

\section{Batasan Konsep}

Terdapat dua konsep yang akan diberikan batasan dalam tulisan ini, yaitu Iklan media cetak dalam rentang periode 1950 - 2000 (diambil satu iklan dalam satu dasawarsa sesuai periodenya), serta aspek kreativitas Komunikasi Visual beserta semiotika yang ada dalam iklan tersebut.

Iklan Media Cetak Adalah suatu pesan media yang statis dan mengutamakan pesan-pesan visual. Media ini terdiri dari lembaran dengan sejumlah kata, gambar atau foto, tata warna dan halaman putih. Pada umumnya unsur-unsur iklan pada media cetak terdiri dari : headline, subhead, body text, splash, closing word, caption, brand name, logo tipe, gambar ( ilustrasi atau fotografi ) dan slogan. Kesepuluh unsur iklan ini merupakan satu kesatuan dalam iklan, namun semua unsur - unsur tersebut tidak selalu dipakai secara berurutan pada sebuah iklan, karena yang utama adalah bagaimana iklan dapat menunjukkan keserasian dan kesatuan dari 
hasil kreatif desainer dalam menyampaikan pesan. (Margolin, 1989)

Sedangkan unsur - unsur komunikasi visual diantaranya terdiri dari tipografi (headline, subhead, body text), warna, gambar, layout ( simetris, asimetris ). (Margolin, 1989).

(1). Tipografi adalah disiplin ilmu yang mempelajari karakter dan fungsi huruf serta adanya pemakaiannya dalam desain komunikasi visual. Huruf merupakan rangkaian terkecil dari sebuah kata. Rangkaian huruf ini tidak hanya memberikan pengertian yang mengacu pada sebuah objek atau gagasan, tetapi juga mampu menyampaikan suatu citra atau kesan secara visual. Headline merupakan bagian terpenting dari sebuah iklan karena merupakan bagian teks yang pertama kali dibaca. Penempatan headline pada posisi tepat, pemilihan tipe huruf disesuaikan dengan tema dan pertimbangan jenis huruf yang digunakan membuat pesan pada iklan mudah dimengerti selain menampilkan unsur - unsur visual lainya (fotografi) .Dalam desain iklan ada subhead yang merupakan penjelasan lanjutan dari headline yang menjelaskan secara singkat mengenai pokok - pokok pikiran, gagasan Subhead dapat memberikan motivasi kepada pembaca untuk terus membaca iklan lebih lanjut pada body teks. Subhead bisa lebih panjang dari pada headline dalam penyajian iklan. Sedangkan body text dalam tampilan headline pada iklan jarang ditemukan karena penyajiannya berupa kalimat panjang yang menerangkan secara rinci tentang formulasi objek utama. Hal yang harus diperhatikan dalam perancangan iklan, bentuk utama body text merupakan penjelasan dari subhead dan headline yang bersifat faktual dan imajinatif melalui pendekatan emosional.

(2). Warna dalam perancangan iklan sangat berpengaruh pada penampilan wujud iklan untuk menarik perhatian dan sugesti pada khalayak. Warna merupakan salah satu unsur yang menghasilkan daya tarik visual iklan. Karena warna lebih menarik secara emosional daripada akal. Warna juga mempercepat komunikasi antara media dengan pembaca. Peranan warna bagi media iklan sangat efektif dalam mendukung proses penyampaian pesan atau gagasan selain itu warna merupakan sarana ekspresi dan dapat memberikan kesan irama pada tampilan fisik media iklan.

(3). Gambar, sebagai salah satu bentuk bahasa yang dapat menyampaikan pesan dan informasi secara visual merupakan kajian utama dalam bidang perancangan grafis dalam rangka mengoptimasikan tujuan komunikasi. Dalam komunikasi periklanan gambar tidak hanya sebagai 
alat informasi dan identitas namun juga persuasi yakni membujuk dan mempengaruhi khalayak ke arah sikap dan perilaku tertentu sesuai dengan yang diharapkan pengiklan. Teknik visualisasi gambar dapat menggunakan teknik tangan atau teknik fotografi.

(4). Layout atau tata letak, mempunyai peranan penting dalam keberhasilan komunikasi visual, karena dengan susunan yang sistematis dan konstruktif akan menciptakan susunan yang teratur, komposisi yang menarik dan berimbang sehingga dapat menarik publik untuk menanggapi isi pesan yang terkandung dalam iklan. Dalam periklanan dikenal adanya dua teknik layout yaitu layout simetris dan layout asimetris. Layout simetris berarti membagi bidang sama besar dan menentukan komposisi letak dari unsur - unsur visual yang dipilih dalam ukuran bidang yang telah ditentukan agar tercapainya sebuah desain yang seimbang, harmonis dan menarik. Layout simetris cenderung berkesan menciptakan keseimbangan desain yang formal, konservatif, tenang dan terkesan kurang dinamis. Sedangkan layout asimetris adalah pembagian bidang yang tidak sama besar dan cenderung adanya keseimbangan yang dinamis, bergerak, hidup, atraktif dan ritmis.sehingga proses komunikasi dan penyampaian pesan makna lebih dari sekedar penampilan.

Sedangkan aspek Semiotika yang dimaksudkan disini adalah kajian yang mengkombinasikan antara unsur nilai estetika pada iklan-iklan rokok yang menggunakan media cetak dan kajian tentang pertanda budaya yang hadir dalam masyarakat sebagai konsumen. Tujuannya adalah mencari titik perspektif yang sama untuk memudahkan pencaritahuan tentang nilai konsumsi masyarakat yang diselubungi oleh iklim pasar. Dari hasil tersebut gejala budaya konsumsi masyarakat akan jauh lebih mudah untuk diketahui sehingga iklan-iklan yang dihasilkan ke masyarakat bisa diterima dengan mudah. (Davidson,1992)

Hal selanjutnya adalah mengenai bahasa komunikasi visual, dalam hal ini terdapat dua golongan, sistem sebagai arbitrary dan motivated. Arbitrary berarti tidak dibuat berdasarkan pengakuan dan kebiasaan, motivated berdasarkan analogi atau persesuaian. sifat arbitrary dan motivated ini sangat berlaku dalam visual iklan. Sistem ini berupa logo teknik atau semacam rekayasa tanda untuk memikat audiens, dan ketika berhadapan langsung, kecenderungan orang akan lansung memahami bahwa gambar yang ia jumpai adalah gambar yang bersifat komersil. Dalam koran, atau pemberitaan media cetak malah sebaliknya karena orang/audiens harus 
menerima gambar tersebut seperti apa adanya. (Roland Barthes, 1972)

Sebagai bahasa, tanda dalam gambar bersifat historis. Sebagai bahasa objek, tanda dalam foto berupa "gesture, attitude, expression,dan efek yang memberikan nilai-nilai khusus bagi audiencenya. Cara yang lazim dilakukan adalah dengan melakukan trik efek. Gejala trik efek justru mempertegas adanya stock of signs semacam ini. Namun hal yang paling utama tentunya berasal dari photogenia (seni foto) yang dilakukan oleh fotografer karena awal terciptanya konsep dan penuangan efek. (Roland Barthes, 1980)

Visual iklan merupakan pranata sosial, sistem nilai, totalitas terstruktur dengan satuan-satuan yang berhubungan satu dengan lainnya, maksudnya adalah sebuah visual harus memenuhi kriteria sebagai bahasa. Dalam melihat visual hal yang membuat audiens merasakan ketertarikannya, adalah ketika mereka memeriksa secara rinci berbagai unsur yang mewujudkan sebuah visual tersebut seperti bentuk, gerakgerik, warna, lighting dan lain sebagainya. Dalam hal ini berarti audiens melakukan penghubungan antara tanda yang satu dan lainnya, sehingga komunikasi visual yang dilakukan sebuah iklan rokok tersebut berhasil.

Dalam iklan prosedur konotatif dapat menghasilkan logo teknik. Yaitu bahasa buatan yang dirancang sepenuhnya secara sepihak dengan maksud mengaktulisasikan kepentingan ekonomi. Dengan logo teknik ini dunia iklan berkembang dari waktu kewaktu. Logo teknik dalam iklan biasanya bekerja untuk membangkitkan naluri-naluri dasar manusia (seks, ketakutan, keintiman, dan bintang atau idola). Logo teknik telah menghasilkan seni tersendiri. Sebagai promosi, iklan seolah menjanjikan kepuasan senikmat kepuasan seksual, rasa aman dari ketakutan, keintiman dari sebuah keluarga, atau bahkan mendekatkan orang kepada sang idola atau bintang. Maksudnya sebuah logo teknik bergerak dalam menciptakan stimuli audiens. Bahasa iklan merupakan bahasa komunikasi yang agresif, komunikasi promosional harus bisa memaksa baik secara halus atau langsung untuk mengubah perilaku konsumen tersebut, gaya hidup, dan akhirnya menjadi konsumen setia. (Barthes, 1972)

Pada umumnya yang terjadi pada audience, mereka melihat visual dua atau tiga detik, kemudian membaca artikel yang tersedia pada iklan, mereka akan langsung mencari visual ini dipakai oleh produk apa, berarti kehadiran visual pada iklan tak lebih hanya sekedar sebagai alat atau indeks dalam mengatasi kebosanan. Dari hal tersebut akan dijumpai keterangan bahwa visual memang memiliki nilai dekoratif atau estetis suatu lay out, atau 
dengan kata lain visual dapat membantu sesorang dalam mengembangkan subjektivitasnya. (Barthes, 1980)

Penggunaan Foto dalam komunikasi visual untuk iklan-iklan rokok yang muncul di era fotografi ada, dapat kita terjemahkan dengan menggunakan konsep yang dikemukakan Barthez, dalam bukunya the photographic message. Beliau mengajukan tiga tahap dalam membaca foto: perseptif, kognitif, dan etis ediologis. Tahap perseptif terjadi jika seseorang melakukan transformasi gambar ke kategori lisan; jadi semacam penjelasan gambar. Konotasi perspektif tidak lain adalah imajinasi segaris dengan unsur bahasa yang pada dasarnya satu titik. Konotasi kognitif dilakukan dengan cara mengumpulkan dan menghubungkan unsur-unsur historis dari denotasi. Konotasi yang dibangun ini atas satu dasar pedoman imajinasi. Pengetahuan kultural sangat menentukan. Tahap ketiga yaitu etis ediologis, orang mengumpulkan berbagai signifier yang siap dikalimatkan. Barthes menunjukkan bahwa tiga cara rekayasa sebagaimana dijelaskan diatas membuka kemungkinan untuk menurunkan signifier. Barthes menyebut signifier pada tingkat konotatif ini dengan sebutan mitos dan signified sebagai idiologi. Ini dibangun dengan imajinasi simbolik. Ketiga tahap ini adalah tahap ide pokok atau penyimpangannya untuk menentukan wacana suatu foto dan moralitas atau ideologi yang berkaitan. (ST.Sunardi, 2002)

Sebelum melakukan pembedahan pada visual yang bisa berupa gambar ataupun foto, ada dua hal yang menjadi teori Barthes, dua konsep yang perlu diketahui itu adalah studium dan punctum. Studium adalah saat seseorang meraba-raba, mengeksplorasi unsur-unsur yang ada dalam visual. Studium sejajar dengan saat mengamati, saat mencoba melakukan penyesuaian terhadap indera dengan objek yang ada dalam visual. Punctum adalah saat orang bergerak dan berhenti pada suatu titik karena titik itu membuatnya terkesan. Pernyataan ini bisa dipahami karena saat studium, adalah saat melakukan pencocokan kode yang ada pada diri orang tersebut dengan kode yang ada dalam visual, sedangkan saat punctum adalah saat orang tersebut menggunakan bahasanya sendiri dalam upaya membantu subjektivitasnya. Bisa juga dikatakan bahwa studium adalah saat seseorang menjajaki diri mereka melalui bahasa publik, dan punctum saat mereka hanya menggunakan bahasa mereka sendiri. Dengan kata lain teori Barthes ini berupa gambaran tentang halusinasi realitas yang digabungkan dengan imajinasi sesorang ketika dihadapkan pada sebuah foto. (ST.Sunardi, 2002)

Iklan bertujuan untuk menciptakan nilai stereotipe. Pilihan visual 
dan cara mengkombinasikannya dengan teks merupakan seni tersendiri, sehingga dapat menciptakan streotipe secepatnya, seluas-luasnya, dan bertahan selama mungkin. Stereotipe pada iklan menjadi menjadi kunci untuk mengubah pikiran dan perilaku konsumen. Sebuah visual bisa mengikat kita bukan karena visual itu sendiri, melainkan karena ditempatkan pada dunia yang direpresentasikan oleh komunikasi dalam iklan. Dunia yang dimana sebuah produk akan mengatasnamakan diri sebagai konsumennya. Atau dengan kata lain identitas seseorang adalah produk yang ia gunakan. Stereotipe ini tidak hanya menawarkan nilai guna, melainkan juga akan nilai sosial, yang tak lain adalah sebuah bentuk pengakuan sosial. (ST.Sunardi,2002)

Sementara itu Teks dalam iklan pada prinsipnya adalah alat yang digunakan sebagai persuasi. Pada iklan kedudukan teks lebih bervariasi. Ada yang berfungsi sebagai caption seperti dalam koran, ada yang menjadi bagian dari gambar itu sendiri, bahkan ada yang ditempatkan secara marjinal seolah-olah tidak penting. Oleh karena itu sebuah iklan lebih leluasa untuk berkembang menjadi sebuah seni persuasi atau retorika. (Yasraf Amir P, 1999). Iklan adalah alat komunikasi yang mengajak orang untuk merubah perilakunya. Karena itu iklan harus menarik perhatian, dengan memberi kejutan. Seperti menurut Rhenald Kasali, iklan adalah pesan yang menawarkan produk yang ditujukan kepada masyarakat lewat suatu media dan manfaat terbesar dari iklan adalah membawa pesan yang ingin disampaikan oleh produsen kepada khalayak ramai.

\section{Perkembangan Visualisasi Iklan Rokok 1950 - 2010}

Pembahasan mengenai Komunikasi Visual menggunakan media cetak tentang produk rokok dimulai dari era 1950an adalah hal yang menarik untuk dijabarkan karena produk rokok adalah produk yang sangat gemar sekali menggunakan iklan untuk menyapa konsumen atau audiencenya. Bila kita berjalan-jalan di sepanjang jalan dekat rumah pasti kita akan menjumpai berbagai iklan produk rokok menyapa mata kita, sehingga sangat menarik sekali apabila kita menengok kreativitas para pembuat iklan di masa 50an hingga sekarang dengan mengambil beberapa contoh iklan yang bisa dianggap sebagai contoh iklan di jamannya.

Pemilihan pembahasan mengenai iklan rokok di tahun 1950an, disebabkan karena baru pada tahun 1950 Indonesia bisa keluar dari kemuraman perdagangan dan ekonomi (Pikat, 2006). Walaupun pada 
waktu itu masih terjadi pemberontakan di daerah-daerah, namun secara nasional Indonesia sudah mulai bangkit. Pabrik-pabrik mulai berproduksi, toko-toko yang terbekalai mulai dibuka kembali dan pasar-pasar mulai ramai, bahkan hotel-hotel sudah mulai berpromosi. Dan yang terlihat banyak pemodal asing menanamkan modalnya di Indonesia sehingga geliat industri mulai berkembang. Indikasi majunya perdagangan dan periklanan di Indonesia saat itu dapat kita lihat pada lembaran Negara yang dikeluarkan oleh Kementrian Perdagangan tahun 1952 yang memuat tentang pendaftaran merk dagang atau etiket pada kementrian tersebut, seperti pada gambar dibawah tentang merk dagang rokok Tjawang.

\section{Gambar 1. Etiket yang muncul di Koran Djawa Baroe}

Tampilan iklan rokok di tahun 1950an bentuk tampilannya kebanyakan hampir sama dengan iklan-iklan buatan tahun 1940an, banyak menggunakan warna hitam putih.

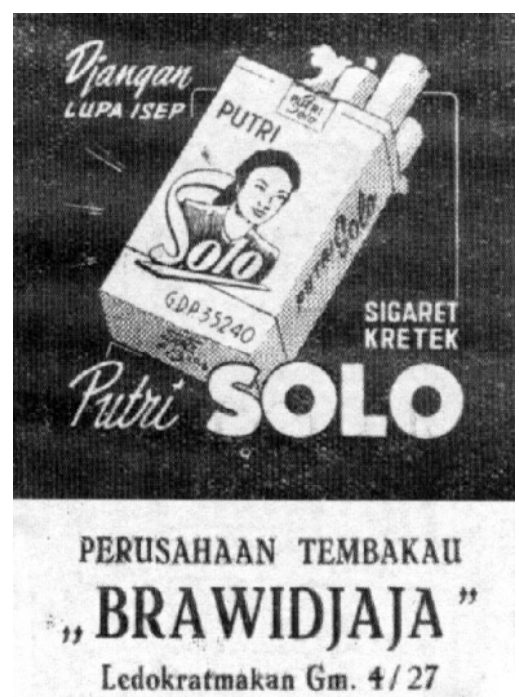

\section{Gambar 2. Iklan Rokok Putri Solo di Dok. Buku 200th Yogya}

Dalam iklan ini Headline yang dikemukakan adalah "Djangan LUPA ISEP" dengan menggunakan tipografi italic, huruf italic ini biasanya digunakan untuk memberikan penekanan pada sebuah kata (Danton, 2001: 32). Umumnya huruf jenis ini memang digunakan dalam teks 
dengan jumlah yang tidak terlalu panjang. Sudut kemiringan yang digunakan adalah $12^{\circ}$ sebagai toleransi kenyamanan dalam membaca. Penggunaan informasi teks yang gamblang dan koheren adalah ciri khas iklan yang dimunculkan pada tahun-tahun 50an ini. Bahasa yang diguakan tampak akrab, ringkas, bahkan cenderung penuh makna. Pada iklan rokok Putri Solo ini visualisasi dan teks sudah menyeret audience kearah permainan citra ke pusaran ekstase visual bahwa rokok ini halus rasanya, dan penggunaan nilai guna juga menjadi andalan pada tema-tema iklan di tahun-tahun 50an ini. Nilai guna adalah nilai dasar suatu barang yang membuat barang tersebut bisa masuk ke pasar karena nilai gunalah yang membuat suatu barang mempunyai nilai (Masa laloe selaloe Aktoeal, 2007). Pada iklan rokok tahun 50an nilai gaya hidup pun sudah dihadirkan, bahkan ditahun ini tembakau dianggap mempunyai nilai khasiat untuk pengobatan, khususnya rokok kretek. Kebiasaan merokok mulai menyebar di pulau Jawa karena adanya kabar bahwa kebiasaan merokok dapat menyembuhkan sakit bengek atau sesak napas. Mula-mula Haji Djamari penduduk Kudus yang menderita sakit di bagian dadanya mempelopori penggunaan minyak cengkeh dalam mengobati penyakitnya dan ternyata penyakitnya mulai sembuh. Dengan naluri bisnisnya maka Haji Djamari mulai membuat "rokok obat" yang diproduksi dalam skala industri rumah tangga dan laku di pasaran. Pada saat itu "rokok obat" lebih dikenal dengan nama "rokok cengkeh", kemudian sebutan tersebut berganti menjadi "rokok kretek" karena bila rokok ini dibakar maka berbunyi berkemeretekan (Budiman dan Onghokham, 1987). Sehingga Visualisasi iklan cetak yang seperti ini pun muncul seperti pada iklan rokok Dieng buatan tahun 1955 di "Madjalah Mesir". Headline maupun bodytext masih menggunakan nilai guna ketika merokok untuk isi iklannya. Tetapi Penggunaan huruf Bold dalam iklan Dieng ini mengharapkan jenis hurufnya dapat memberikan kesan yang berbeda, jelas dan mempunyai potensi yang kuat dalam menarik perhatian mata (Danton, 2001 :28). Pada iklan-iklan yang muncul pada era ini masih bersifat lokal karena penyebaran media yang ada pun hanya bersifat lokal dalam pendistribusiannya. Penggunaan bahasa lokal mencitrakan produk ini untuk konsumen pribumi 


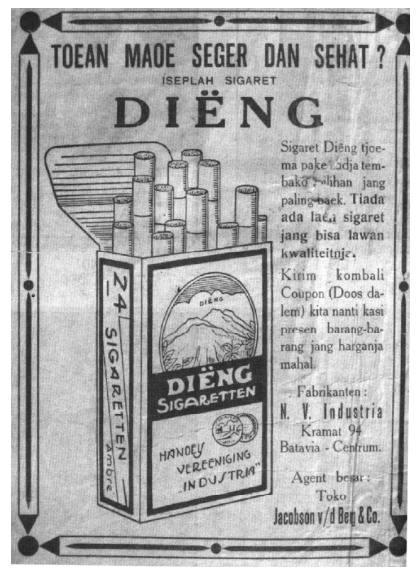

\section{Gambar 3. Iklan Rokok Dieng di Madjalah Mesir, 1955}

Orientasi yang muncul pada komunikasi visual iklan-iklan pada tahun 50an sangat hardsell, promosi untuk secepatnya dapat meraih konsumen. Penggunaan jenis Layout simetris mendominasi iklan-iklan keluaran tahun ini, cenderung berkesan menciptakan keseimbangan desain yang formal, konservatif, tenang dan terkesan kurang dinamis. Pada tahun 50an ini masih banyak dijumpai iklan yang berbentuk "literer" seperti iklan rokok Dieng. Yang dimaksud literer adalah bentuk komunikasi yang bersandar pada bahasa verbal yang tertulis dan tercetak (Wicaksono, 2006). Tetapi bahasa tulis ini tidak menunjuk pada tingkat membaca masyarakat Indonesia pada masa itu, karena tingkat keberaksaraan pada masa itu kurang dari lima persen ari seluruh masyarakat indonesia. Paradigma literer yang dimaksud adalah bahwa komunikasi dalam teks cetak merupakan tindak komunikasi yang membutuhkan intensitas intelektual, pada dasarnya iklan literer menyajikan suatu logika tertentu. Dalam iklan literer yang penting bukan kebenaran faktualnya melainkan bagaimana proses penyusunan proposisi tahap demi tahap sehingga penyimpulannya menjadi logis.

Untuk iklan di tahun 60an, iklan yang ada mulai bergerak kepada halaman berwarna, warna mulai digunakan untuk memperkuat citra produk seperti yang tergambar pada iklan rokok Bond Street berupa selebaran yang muncul di tahun 1968 (Pikat, 2006). Warna menjadi unsur tersendiri untuk menarik perhatian walaupun teknik percetakan yang ada masih walau sebatas pewarnaan sederhana. Warna dapat menghasilkan daya tarik visual dan emosi. Pencitraan atau imagology seperti yang digambarkan Yasraf Amir Piliang (Mediator Vol 5, 2004) mulai dijadikan 
strategi dalam berkomunikasi. Teks yang dimunculkan "Lain Daripada yang Lain Dengan Tembakau Virginia Asli" membentuk sebuah ilusi bahwa ini adalah produk impor yang akan "sangat" dapat memenuhi selera konsumen. Citra ini menciptakan, membentuk dan mengatur tingkah laku konsumen agar rokok Bond Street ini dianggap sangat berguna dan terbaik dikelasnya. Konsumen diarahkan untuk membeli rokok ini disebabkan imagenya yang "impor" ketimbang nilai gunanya.

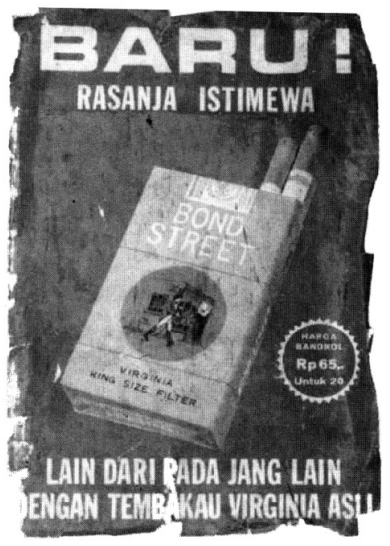

\section{Gambar 4. Selebaran Rokok Bond Street tahun 1968 (dok.Bentara Budaya)}

Penggunaan huruf Bold sangat mendominasi dalam iklan Bond Street ini agar iklan ini mudah dibaca, dan penggunaan Flash dalam menginformasikan harga rokok pun disertakan agar iklan ini benar-benar informatif dan menonjol. Penggunaan layout dengan jenis Frame Layout banyak digunakan dalam era iklan rokok tahun 50-60an karena jenis layout ini sangat mudah dan sangat readable. Frame layout adalah adalah format layout dengan border di pinggarnya, dan visual tampak berada ditengah dengan border kadang merupakan rangkaian dari produk yang diiklankan (Santosa, 2002:48).

Ditahun 70an, iklan mulaibergerak kearah bewarna seiring munculnya teknologi audio visual di Indonesia dengan didukung kemunculan TVRI. Dalam siarannya TVRI mulai dapat menghasilkan gambar yang menarik walaupun masih hitam putih, tetapi dapat mendorong media cetak untuk lebih berkembang. Dengan penggunaan warna dalam visualisasinya pembuat iklan berharap dapat memaksimalkan respon psikokogis (warna 
dapat membantu menyatakan kehangatan, kedinginan, kualitas, rasa hati dan emosi lainnya karena warna didasarkan pada tabiat manusia) bahkan Fisiologis (warna menarik perhatian). Pada periode 70an ini iklan cetak rokok cenderung lebih berani atau vulgar dalam menampilkan karya visualnya, visualnya menunjukkan bentuk rokok, kemasan, dan aktivitas merokok secara nyata. Aktivitas merokok bukan menjadi barang tabu dan efek terhadap kesehatan pun belum terlalu diindahkan. Iklan dapat lalu lalang dengan santainya di mata konsumen dengan terang-terangan, aturan mengenai tampilan visual iklan belum diatur secara ketat, bahkan iklan rokok dapat masuk di jam tayang iklan di TVRI yang potensial. Seperti pada iklan rokok Commodore di bawah ini,

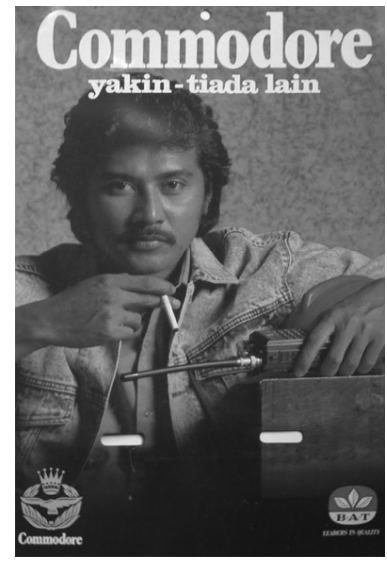

\section{Gambar 5. Iklan Rokok Commodore tahun 70an}

(dok.4.bp.blogspot.com)

Kejantanan dan kegagahan ketika beraktivitas merokok diperlihatkan secara terang-terangan dengan headline "Yakin, tiada lain" memperlihatkan bahwa si perokok yang tampan, gagah pilihannya hanya satu rokok tersebut. Rokok Commodore adalah rokok yang terkenal pada masanya, dalam iklan ini tidak terlihat penanda (signifier) sebuah bungkus rokok sebagai sebuah produk yang dijual, konsumen dikondisikan untuk tidak lagi membeli produk untuk pemenuhan kebutuhan (nilai guna) tetapi membeli maknamakna simbolik yang tampak pada talent rokok tersebut yang gagah dan tampan. Konsumen diciptakan untuk lebih terpesona dengan maknamakna simbolik dalam komunikasi visual ini. Pada era 70 an, iklan produk rokok kebanyakan menciptakan visualisasi sang talent dalam iklan rokok 
adalah laki-laki yang sukses, gagah, tampan dan sehat berbalik dengan kenyataan bahwa rokok adalah termasuk penyebab penyakit pembunuh manusia seperti kanker, dan penyakit berat lainnya. Kreativitas yang baik belum menjadi pilihan di tahun 70an, karena pembuat iklan masih menggunakan konsep hardsell dan menonjolkan citra yang dihadirkan untuk sebuah impian layaknya talent pada iklan Commodore diatas. Pencitraan adalah sebuah strategi penting didalam komunikasi visual di sebuah iklan, didalamnya konsep, gagasan, tema atau ide-ide dikemas dan ditanamkan dalam sebuah produk, untuk dijadikan sebagai memori publik. Kegagahan yang dikembangkan dalam produk ini hanyalah sebuah ilusi, ilusi ini adalah cara yang digunakan untuk mendominasi selera masyarakat agar mereka mempunyai niat untuk mencoba produk yang ditawarkan.

Iklan merupakan sebuah proses komunikasi yang bertujuan untuk membujuk orang untuk mengambil tindakan yang menguntungkan bagi pihak pembuat iklan. Iklan ditujukan untuk mempengaruhi perasaan, pengetahuan, makna, kepercayaan, sikap, pendapat, pemikiran dan citra konsumen yang berkaitan dengan suatu produk atau merek, tujuan periklanan ini bermuara pada upaya untuk dapat mempengaruhi perilaku konsumen dalam membeli sebuah produk yang ditawarkan. Kreatif iklan Sejak tahun 1980-an mulai dilirik sebagai seni di Indonesia, kreatif iklan menjadi diskusi tersendiri (Gong Edisi 90, 2007). Tujuan dan orientasi iklan pun berkembang dari yang hanya sekedar promosi untuk secepatnya mendapatkan atau meraih konsumen ( $h a r d$ sell), menjadi pendorong hasrat konsumen untuk loyal pada merek (brand image) dan bukan produk. Bentuk iklan mulai mengandalkan artistik yang metaforik bagi komunikasi visualnya. Unsur seni dalam sebuah produk iklan sudah tidak sekedar sebagai pelengkap promosi semata. Biro iklan mulai banyak tumbuh ditahun 80an didukung oleh kementerian penerangan Ali Moertopo yang mengakui eksistensi dunia iklan di Indonesia, dan juga dikukuhkannya kode etik periklanan yang mengatur visualisasi dan isi iklan (Reka Reklame, 2005 : 133) juga mulai pekanya bahwa seni dalam visualisasi iklan mulai sebagai tulang punggung dalam kreativitas visual. Bahwa kreativitas mulai sangat berkembang karena dihentikannya iklan niaga di TVRI mulai 1 April 1981 menciptakan biro iklan untuk berkomunikasi visual dalam iklan untuk lebih kreatif. Seperti iklan Rokok Commodore yang sudah mulai menggunakan bahasa simbol daripada menggunakan bahasa yang vulgar atau hardsell. 


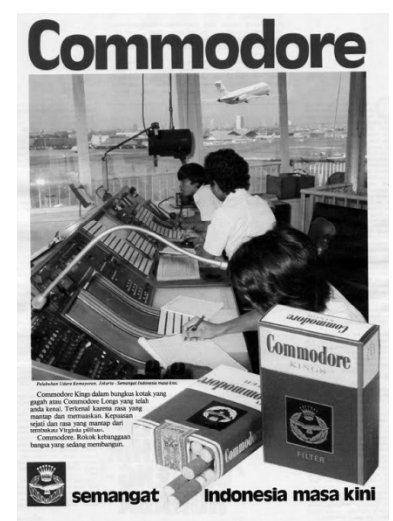

\section{Gambar 6. Iklan Rokok Commodore tahun 80an (dok.koleksi barangjadoel.blogspot.com)}

Adanya kode etik Periklanan Indonesia yang kemudian disebut Tata Krama dan Tata Cara Periklanan Indonesia ini yang mengatur isi dari iklan-iklan yang ditayangkan ke konsumen, sehingga produk rokok mulai mencari strategi pesan agar aktivitas merokok tidak diperlihatkan dalam iklan. Para pelaku industri periklanan di tahun 80an mulai berkreasi dalam berkomunikasi ke konsumen. Tetapi gaya layout dan pemilihan huruf tidaklah jauh berbeda dengan era-era sebelumnya masih menggunakan simetris layout walau jenis Layoutnya berjenis Picture window layout karena ada aktivitas fotografi disana yang mempengaruhi jenis pemilihan layout-annya, dan pemilihan huruf Bold masih digunakkan untuk lebih memperjelas isi. Bahkan Seorang fotografer yang akan membuat pesan terlebih dahulu telah mengerti konteks yang akan dihadirkan. Oleh karena itu dipilih cara dan bentuk serta ekspresi yang mereka percaya akan sangat jelas dapat dimengerti oleh orang lain. Di sisi lain, karena komunikasi merupakan bagian dari struktur sosial yang ditandai dengan perbedaan-perbedaan, maka setiap konsumen harus berusaha memahami hingga dapat benar-benar paham, Atau cara lain yang harus ditempuh oleh fotografer tersebut adalah dengan menyesuaikan unsur-unsur nilai, budaya dan tatanan yang berlaku pada audience. Sedangkan kreativitas visual mulai berkembang kearah citra image untuk menawarkan sebuah brand bukan hanya sebuah produk. Citra dapat mengkomunikasikan kelas, status sosial dan gaya hidup seseorang, seperti yang dicitrakan rokok Commodore dengan menampilkan foto ruang kontrol Bandara 
yang diartikan Teknologi Tinggi, modern, dan mempunyai kelas sosial tinggi. Dengan gaya visual seperti ini keadaan kreativitas iklan mulai bergerak kearah menonjolkan ide yang ditanamkan dalam komunikasi visualnya. Pengendalian selera, gaya hidup, tingkah laku, aspirasi serta imajinasi diciptakan oleh para pembuat iklan untuk mengendalikan citra yang dihadirkan ke konsumen, yang sesungguhnya citra yang diciptakan tidak berkaitan dengan produk yang diiklankan. Para pencipta iklan hanya menampilkan ilusi dan manipulasi visual agar konsumen tergerak untuk membeli produk rokok yang ditawarkan. Dalam pemaknaan iklan pada era 80an diarahkan sebagai sebuah tontonan yang menciptakan berbagai tanda, citra dan makna untuk kepentingan agar produk yang ditawarkan laku.

Aturan visual dalam iklan rokok mulai digulirkan secara ketat bahkan Berdasarkan PP No. 81 tahun 1999, semua iklan rokok di Televisi dilarang. Namun, karena pihak Televisi memprotesnya, muncul PP No.38 Tahun 2000 tentang Pengamanan Rokok bagi Kesehatan. Dalam PP yang baru ini, iklan rokok di Televisi hanya boleh ditayangkan pukul 21.30 hingga 05.00. Penayangan iklan rokok pada malam hari ini bertujuan agar tidak ditonton anak-anak. Regulasi ini sedikit banyak mempengaruhi komunikasi visual dalam iklan rokok, para pelaku kreatif iklan mulai bergerak mencari kreativitas yang dianggap menampilkan inovasi dan mempunyai nilai seni yang baik. Visual yang ada pada iklan rokok di era 90an -hingga akhir 2000an. Iklan rokok yang dianggap mewakili era ini adalah iklan rokok A Mild produksi Sampoerna.

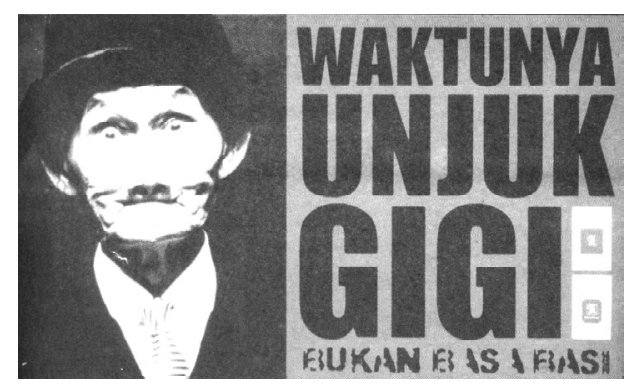

Gambar 7. Iklan Rokok AMild

Iklan produk rokok mild mendominasi iklan, hal ini dikarenakan rokok mild merupakan terobosan baru pada pasar Indonesia yang tengah dikuasai oleh rokok kretek. Tahun 1989, rokok mild menjawab keinginan pasar dan digemari anak muda, sehingga menjadi budaya Pop yang mewakili 
generasi. Hal ini karena rokok mild terkesan lebih "sehat" serta didukung dengan iklannya yang menyuarakan isi hati dan keinginan anak muda yang cenderung memberontak terhadap peraturan yang ada. Tak kalah dengan rokok kretek, rokok mild juga mempromosikan produknya melalui iklan. Kecenderungan menyimpang dari visualisasi iklan yang sudah ada menjadi trend untuk iklan rokok A Mild, perubahan ini karena trend dunia yang memang mengarah kearah seperti itu didukung oleh penghargaanpenghargaan untuk sebuah iklan yang menurut asosiasi tertentu terlihat "kreatif". Perubahan itu mengandung sikap pandangan yang baru, tak terduga, mengejutkan dan menghebohkan. Konstelasi perubahan itu disebabkan mulai banyaknya media untuk beriklan sehingga iklan di media cetak diharapkan segar, orsinil, dan mampu mencari perhatian. Nilai-nilai visual iklan lama mulai ditata kembali yang tidak hanya sekedar menjual produk tetapi menjual citra ataupun brand.

\section{Kesimpulan}

Iklan adalah pesan yang menawarkan produk yang ditujukan kepada masyarakat lewat suatu media dan manfaat terbesar dari iklan adalah membawa pesan yang ingin disampaikan oleh produsen kepada khalayak ramai. Terkadang Komunikasi Visual yang disampaikan oleh iklan di plot sehingga membuat masyarakat untuk berperilaku konsumtif. Iklan adalah ujung tombak, dalam hal ini adalah salah satu dari bagian penting pada proses tercapainya kesuksesan suatu program sosialisasi, dengan kata lain Komunikasi Visualnya memegang peranan dalam mencapai tujuan produsen atau si pengirim pesan utama. Untuk itu dalam penyampaiannya iklan selalu menggunakan teknik tertentu untuk mencapai tujuannya. Kegiatan Komunikasi Visual dalam Iklan rokok 1950-2000 sebenarnya secara pengemasan pesannya mulai berkembang di akhir tahun 90an dengan mulai adanya trend visualisasi iklan yang modern dengan lebih menonjolkan kemampuan mengemas pesan dengan cara yang "baru", iklan mengandung orisinalitas yang lebih menarik keluar dari jalur pesan secara vulgar tanpa daya kreativitas yang unggul hanya mengulang cara-cara lama dalam berkomunikasi visual.

\section{Daftar Pustaka}

Amir, P. Yasraf. 1999. Hipersemiotika, Bandung-Yogyakarta: Jalasutra.

Amir, P. Yasraf. 2004. Iklan, Informasi, atau Simulasi?.:Konteks Sosial dan 
Kultural Iklan.. Bandung.. Jurnal Komunikasi Unisba Volume 5 No.1.

Barthes, Roland. 2007. Membedah Mitos-Mitos Budaya Massa. BandungYogyakarta: Jalasutra,.

Chaney, David. 2005. Lifestyle. Bandung-Jakarta: Jalasutra.

Kasali, Rhenald.1993. Manajemen Periklanan. Jakarta. Grafiti

PPPI. 2005. Reka Reklame Sejarah Periklanan Indonesia 1744-1984. Yogyakarta : Galang Press,

Santosa, Sigit. 2002. Advertising Guide Book. Jakarta : PT Gramedia Pustaka Utama,

Sunardi, ST. 2004. Semiotika Negativa. Yogyakarta : Buku Baik,

Sihombing, Danton. 2001. Tipografi : dalam Desain Grafis. Jakarta : Gramedia Pustaka Utama.

\section{Sumber lain :}

http://pemoeda-pemoedie.blogspot.com/2007/10/sejarah-singkat-rokokkretek-indonesia.html

Katalog Pameran Iklan Koenoe, Tembi 25 Mei - 16 Juni 2007

Katalog Pameran Iklan Cetak Generasi ke 2 (PIKAT), Bentara Budaya Yogyakarta 13 -21 Januari 2006

Majalah Gong Edisi 90/VIII/2007 "Iklan Mengenang, Membujuk, Menghibur" 